WORKING PAPER NO. 3

Sept 1994

\title{
A Generic Plant Functional Attribute Set and Grammar for Vegetation Description and Analysis
}

\author{
Andrew N. Gillison and Guy Carpenter
}

Summary

Conventional descriptive methods rarely convey the behavioural information needed to conserve and manage the world's vegetation. Such information may be derived from a generic set of plant functional attributes (PFAs). A grammar provides a syntactic rule base for generating and comparing coherent models of individual plant behaviour based on PFA combinations rather than discrete attributes. The method facilitates rapid and uniform assessment of plant response to environmental change at varying spatial scales regardless of species.

CENTER FOR INTERNATIONAL FORESTRY RESEARCH

office address: JaIan Gunung Batu 5 Bogor 16001 Indonesia mailing address: P.O. Box 6596, JKPWB Jakarta 10065 Indonesia tel.: +62(25 1) 34-3652 fax:+62(25 1) 32-6433

email: cifor@cgnet.com 


\section{The CGIAR System}

The Consultative Group on International Agricultural Research (CGIAR) is an informal association of 41 public and private sector donors that supports a network of sixteen international agricultural research centers, CIFOR being the newest of these centers. The Group was established in 1971. The CGIAR centers are part of a global agricultural research system which endeavor to apply international scientific capacity to solution of the problems of the world's disadvantaged people.

\section{CIFOR}

CIFOR was established under the CGIAR system in response to global concerns about the social, environmental and economic consequences of loss and degradation of forests. It operates through a series of highly decentralized partnerships with key institutions and/or individuals throughout the developing and industrialized worlds. The nature and duration of these partnerships are determined by the specific research problems being addressed. This research agenda is under constant review and is subject to change as the partners recognize new opportunities and problems. 


\title{
A Generic Plant Functional Attribute Set and Grammar for Vegetation Description and Analysis
}

\author{
Andrew N. Gillison ${ }^{1}$ and Guy Carpenter ${ }^{2}$
}

\begin{abstract}
Summary
Conventional descriptive methods rarely convey the behavioural information needed to conserve and manage the world's vegetation. Such information may be derived from a generic set of functional plant attributes (PFAs). A grammar provides a syntactic rule base for generating and comparing coherent models of individual plant behaviour based on PFA combinations rather than discrete attributes. The method facilitutes rapid and uniform assessment of plant response to environmental change at varying spatial scales regardless of species.
\end{abstract}

Traditional methods of vegetation description are primarily designed to convey visual rather than behavioural information; the descriptors cannot be used to construct coherent models of plant behaviour. Yet a knowledge of plant response to environmental change is fundamental to conserving and managing the world's vegetation.

Inconsistencies between attribute sets used to define arbitrarily distinct vegetation types such as rain forest and savanna also inhibit the quantitative assessment of vegetational change along physical environmental gradients. We present a method for describing and quantitatively comparing any assemblage of vascular plants by using a grammar based on a generic set of behavioural or functional attributes. Other, more detailed features, such as life-history attributes may be added where necessary and where available, to this core set. The language defines an explicit rule set for defining linkages between 36 plant functional elements within six attribute classes. Unlike open-ended classifications based on Raunkiaerean life form, the grammar creates a finite universe for describing any vascular plant according to a specific combination or modus of functional elements. Also, unlike most descriptive methods which delineate attributes as separate, unconnected components, each modus represents a coherent, functional model of the plant photosynthetic envelope and a vascular support system. The grammar provides a unique way of accessing the combinatorial information within a modus. This additional structure provides a more sensitive basis for comparing functional aspects of individuals and stands of individuals than methods which address only discrete elements. Minimum spanning tree networks of modi can be used independently of taxa to display functional 'distances' within and between plant assemblages. The functional grammar provides an explicit framework for dynamic vegetation studies that is unavailable through traditional visual-descriptive recording techniques. The method can be used to measure congruence in plant functional data between sets of geographically remote and taxonomically different individuals. Implications for vicariance biogeography, vegetation dynamics and rapid vegetation survey are briefly addressed.

The efficient use of plants as indicators of habitat and habitat modification requires a priori knowledge of features which best reflect plant response to known environmental determinants. In this respect coherent sets of response-based (functional) attributes are preferable to incoherent or unconnected sets of structural, physiognomic or floristic descriptors that are designed to convey essential visual impressions of vegetation for descriptive purposes. Although the latter are of limited value for dynamic investigations, they have the advantage of being relatively few and simple (Fosberg, 1967; Kuchlcr, 1967; Dansereau,

\footnotetext{
${ }^{1}$ Center for Intcrnational Forestry Research, P.O.Box. 6596 JKPWB, Jakarta 10065, Indonesia.

2 Tropical Forest Research Centre, CSIRO Division of Wildlife \& Ecology, P.O. Box 780 Atherton, Queensland 4883, Australia.
} 
1957). The definition and application of existing functional descriptors such as 'life-form' and 'growth form' on the other hand, remain uncertain and complex (Fosberg, 1967; Riibel, 1930; Schimper, 1964; Raunkiaer, 1934; Warming, 1909; Eriksson et al., 1992; Gimingham, 1951; Adamson, 1939).

\section{Limitations of methods to date}

The need for a generic method of recording dynamic aspects of vegetation is highlighted by the limitations of present-day classification systems (Fosberg, 1967; Küchler, 1967; Dansereau, 1957; Eiten, 1960; Specht et al., 1974) that are mostly hybrids of visualdescriptive and functional variables. Development of earlier, 'response-based classifications (Schimper, 1964) has been hindered by the lack of relevant ecophysiological theory and, until relatively recently, appropriate methods for analysing complex data sets across varying environmental and geographic scales (Belbin, 1992; Box, 1981; Woodward, 1987).

The most successful generic vegetation classification method thus far is the life-form system of Raunkiaer (Raunkiaer, 1934) which is based on a single functional criterion - the position of the perennating bud during the most unfavourable season. Raunkiaer's method contrasts with other, more complex, system (Riibel, 1930; Du Rietz, 1931 ; Cain, 1950) in that it can be more-or-less correlated with climate (Raunkiaer, 1934; Adamson, 1939; Woodward, 1987). Raunkiaer compensated for shortcomings in his system by adding growthform qualifiers such as epiphyte and liane (Fekete, 1972). Although subsequent extensions to Raunkiaer's system have been widely used in western Europe and the Middle East (BraunBlanquet, 1932; Ellenber et al., 1966; MuellerDombois et al., 1974; Orshan, 1983), they are impractical in complex tropical vegetation, either because of uncertain functional delinition or else unwieldy attribute combinations. While other functional approaches based on life history strategies (Grime, 1979; Noble, 1980) offer more comprehensive and more specific models of plant behaviour, these are limited to applications where life histories are already known or where operational definitions of functional phenomena e.g. 'stress'(Grime, 1979) are unambiguous.

\section{A generic set of Plant Functional Attribute descriptors and functional modi}

Whereas functional attributes are traditionally associated with periodicity (Fosberg, 1967; Ktichler, 1967; Dansereau, 1957; Raunkiaer, 1934), we assert certain other attributes such as leaf size class (commonly used for visualdescriptive purposes) can take on functional meaning when combined with leaf-inclination and other morphological (e.g. dorsiventral) and temporal (e.g. deciduous) descriptors of chlorophyll distribution.

We have modified an earlier plant functional attribute set (Gillison, 1981) that describes a plant individual as a two-component, functional model (photosynthetic envelope and vascular support system). The photosynthetic envelope is described according to the most repetitive functional 'leaf unit using four attribute classes (size, inclination, chlorotype and form). Together these define the spatial and temporal distribution of photosynthetic leaf and stem tissue. The vascular support system is described according to a class of pure Raunkiaerean life forms and a class of aboveground rooting systems (Table 1). Following the method of Gillison (Gillison, 1981) a functionally integrated or coherent set of these descriptors for an individual is termed a modus. A typical modal descriptor for Eucalyptus populnea might be:

'no-pe-is-ph'

(Notophyll-Pendulous-Isobüateral-

Phanerophyte

We emphasize that a modus describes an individual, not a taxon. A species may be represented by multiple modi and a modus may represent multiple species - i.e. the speciesmodus transformation is a many-to-many mapping. Unlike floristic decriptors, the modal system is therefore sensitive to genecotypic variablity. It makes no assumptions about guild structures (Schimper, 1964; Johnson, 1981) or life history strategies (Grime, 1979; Noble, 1980) but presents instead, a functional 'snapshot' of an individual via a minimum attribute set that reflects core attributes of growth, physiology and survival. The modus provides a unique structure 
for defining functional models as integrated systems based on functional morphology rather than on trophic groups or life-history strategies (Grime, 1979; Noble, 1980; Johnson, 1981; Bahr, 1982; Vogel, 1991).

As presented, the system avoids the pitfalls of using discrete or unconnected, singular variables such as leaf size class and the attendant problems of functional interpretation. Survey data acquired to date using this method correspond more closely with physical environment and the distribution of some animal biota than either floristics or broad vegetation structure (Nix et al., 1985; Fox et. al., 1981). (A proforma structure and an introductory rationale for the selection of plant functional attributes are available (Gillison, 1981; Gillison, 1988). The plant functional attribute (PFA) set has been iteratively selected from within a wide range of global sites which, we emphasize, represents a core attribute set to which other lifehistory attributes can be attached where required and where available.

\section{A syntactic, rule-based, grammar}

Until now, our inability to utilize the combinatorial information contained within a modus has restricted the labeling of data to either unconnected modal elements or, as with taxa, to a unique numeric identifier for each modus. We are now able to access combinatorial information via a grammar which defines precisely how plant functional attributes and elements may be coupled. Using the grammar, we also describe a quantitative method for analyzing differences between modi. These differences are conveyed via multidimensional scaling and minimum spanning trees (MSTs). Case studies at three biogeographic scales illustrate how an MST can be used to display modal similarities within and between sites.

The PFA grammar (Fig. 1) represented graphically and in Backus-Naur form (Gillison, 1988) provides an unambiguous definition of attribute combinations which constitute valid modi. The use of a grammar allows us to develop syntactic rules which enforce constructs such as mutual exclusivity between attributes. A table of transformations weighted subjectively (Table 2), prescribes costs to attribute transformations based on the relative difference between modal states (analogous to character-weighting of operational taxonomic units in numerical taxonomy). This facilitates quantitative comparison between modi. Rules exist to

substitute one attribute for another, to create and to extinguish attributes. For example while we allocate a transformation cost of 1 between adjacent leaf size classes, creation or extinction of adventitious rooting has a cost of 3 . Transition rules for some classes, such as leaf size, require multiple substitutions to transit to non-adjacent forms. For example a translation form nano to noto involves a nano->micro substitution followed by a micro->noto substitution. A set of 46 rules provides sufficient richness to transform any modus into any other modus using a series of transformations. The distance between two modi, $\mathrm{A}$ and $\mathrm{B}$, is thus defined as the minimum cumulative cost required to 'transform' $\mathrm{A}$ into B. This method defines a Levenshtein distance metric (Sankoff et. al., 1983) over the set of all possible modi. .The transformation table contains no zero-cost transformations, no asymmetrically costed transformations, and consequently the distances satisfy the formal properties of a metric, i.e.:

\section{(a) positive definiteness:}

$\mathrm{d}(\mathrm{a}, \mathrm{b})$ is a positive real number for $\mathrm{a} \ddot{\mathrm{A}} \mathrm{b}$ and is zero for $\mathrm{a}=\mathrm{b}$

(b) symmetry : $d(a, b)=d(b, a)$

(c) triangle inequality: d(a,c) $<=d(a, b)+d(b, c)$

Because our primary concern is to develop a metric, we assume equi-directional transformation costs between all modal elements (i.e. we define all transformation rules symmetrically, such that: $A->B=B->A)$. For asymmetric transformations (A->B $\ddot{\mathrm{A}} \mathrm{B}->\mathrm{A})$ the inter-modal distances cease to be a metric as they violate the symmetry property and thus require different analytical methods.

\section{Applications at varying spatial scales}

Figure 2 shows a minimum spanning tree generated from the distance matrix for all modi within a site in a north Queensland rain forest. The distance between modus A (no-pe-do-ph-li) and modus K (no-ve-do-de-ct-ph-ad) is calculated by summing costs of the required transformations:

no-pe-do-ph-Ii
no-la-do-ph-Ii
no-ve-do-ph-Ii
no-ve-do-ph-Ii-de
no-ve-do-ph-Ii-de-ct
no-ve-do-ph-de-ct

no-pe-do-ph-Ii

no-la-do-ph-Ii

no-ve-do-ph-I

no-ve-do-ph-Ii-de-ct

$$
\begin{array}{r}
\text { pe }->\text { la }: 2 \\
\text { la }->\text { ve }: 2 \\
->\text { de }: 3 \\
->\text { ct }: 3 \\
\text { Ii }->\quad: 3 \\
\text { ad }: 3
\end{array}
$$

Total 16 
The availability of an inter-modal distance metric permits analysis of vegetation assemblages using standard quantitative analysis methods. A multidimensional generalization of the WaldWolfowitz two-sample test (Friedman et al., 1979) in conjunction with multidimensional scaling, has proven useful for comparing and visualizing vegetation assemblages. The WaldWolfowitz test is used to estimate the probability that two samples originate from the same population. A complete inter-site association matrix of variance values can be compiled for a given set of PFA-sampled sites. Figures 2 and 3 give examples of two such sets at differing geographic scales.

Although the language defined by the grammar contains all syntactically or logically valid modi, not all such models are realizable in practice, due to physiological and architectural constraints. For example, the syntactically valid modus mega-vertic-solido-epi-cham is mechanically inoperable. This is analogous to other combinatorial models such as those for shell spirals (Raup, 1966) where only a small subset of geometrically possible models has been observed. A supplementary semantic rule-set under development will help generate a more realistic 'periodic table' of observed ind potential modi. While it is important for ecological applications to understand the functional limitations of potential modi, for computing purposes the potential number of combinations is largely irrelevant.

\section{Implications for studies of vegetation dynamics and conservation management}

The system has a number of advantages for field operations. Firstly, the PFA set can be used by observers with little training to obtain highly repeatable observations. Secondly, while floristic coding of modal assemblages is ultimately desirable, there is no a priori need for species identification. Thirdly, we argue the PFAs represent core adaptations to the physical environment and, for general purposes, reduce the need for detailed knowledge of life history attributes. Fourthly, because the system is generic, PFAs can be applied to any assemblage of vascular plants.

The relevance of the method to studies of vegetation dynamics is illustrated in Fig. 3 where the MST corresponds with both a readily identifiable vegetational sequence and a rainfall seasonality gradient. As portrayed in Figs. $3 \& 4$, comparisons can be made between geographically variable and taxonomically different modal assemblages to measure congruence among functional attribute sets. Such measures are potentially useful in refining broadscale spatial models of on-ground performance for species or genotypes that have been derived by matching known performance profiles with regional homoclimes (Box, 1981; Booth, 1990). Congruence of this kind may be useful for evaluating vicariant patterns of functional characteristics between sets of individuals or taxa within and between continents.

The rule-set contained in our grammar, together with the subjective weightings between transition states, are clearly approximative and greatly simplified. Nonetheless they provide for the first time a mechanism for generating a finite framework for analyzing plant performance in terms of integrated sets of readily observable, functional variables. The method allows questions about plant adaptation to the physical environment to be formulated in a way that avoids sole reliance on discrete variables (e.g. leaf size). A better understanding of the adaptive role of PFAs may thus be achieved by seeking reasons for the occurrence or nonoccurrence of certain attribute combinations in nature.

A number of advantages arise from the use of the grammar. For example, distance matrices are well-suited to exploratory data analyses (Belbin, 1992; Raup, 1966) and illegal PFA combinations can be detected during the compilation of data. For studies of vegetation dynamics, the grammar can be used to explore functional differences along successional pathways and to monitor, and thus help predict, vegetation response to environmental impact.

Although the grammar deals with phenetic rather than phylogenetic variables, some cladistic algorithms may be applied to modal data for exploratory purposes. More direct cladistic analysis may be appropriate where there is evidence for canalization and evolutionary direction of specific attribute sets (Farris, 1972; Swofford, 1992). When coupled via the grammar as modi, PFAs may indicate genecotypic variability among plant assemblages that is otherwise undetectable by functional elements alone, or by floristics or by vegetation structure or physiognomy. Recent use of minimum spanning path distances to estimate phylogenetic diversity via the feature diversity of subsets of taxa (Faith, 1992) also suggests an analogous use of the PFA grammar for estimating 
functional richness as a partial measure of plantbased biological diversity. The addition or subtraction of plant assemblages as functional modi to or from a known MST structure may be used to assess representativeness of target areas for conservation management purposes.

Acknowledgements. We are much indebted to Mike Dale for his initial help and valuable criticism. David Christophel, Peter Cranston, Francis Crome, Dan Faith, Habiba Gitay, Francis Hallé Marianne Horak, Bernie Hyland, Ian Noble and Brian Walker kindly commented on later drafts.

\section{References}

Fosberg, F.R. in Guide to the Checklistfor I.B.P. Areas. (ed. Peterken, G.F.) (I.B.P. Handbook No. 4, Blackwell Scientific Publ.,Oxford, 1967).

Küchler, A.W. Vegetation Mapping (Ronald Press, New York, 1967).

Dansereau, P. Biogeography: an Ecological Perspective. (Ronald Press,New York, 1957).

Rütbel, E. Pflanzengesellschaften der Erde (Bem, Berlin, 1930).

Schimper, A.F.W. Plant Geography Upon a Physiological Basis., Historiae Naturalis Classica II. (Wheldon and Wesley,Codicote, 1898) (repr. Cramer, Weinheim, 1964).

Raunkiaer, C. The Life Forms of Plants and Statistical Plant Geography. (Clarendon Press, Oxford, 1934).

Warming, E. Oecology of Plants Engl. transl. by M. Vahl, P. Groom \& I.B. Balfour. (Clarendon Press,Oxford, 1909).

Eriksson, O., Bremer, B. Evolution 46, 258-266 (1992).

Gimingham, C.H. J. Ecol. 39, 396-406 (1951).

Adamson, R.S. Bot. Rev. 5, 546-561 (1939).

Eiten, G. Bol. Inst. Bot. 4, 1-88 (1960).

Specht, R.L., Roe, M.E. \& Broughton, V.H. Aust. J. Bat. Suppl. Ser. 7, 1-667 (1974).

Belbin, L. PATN Pattern Analysis Package; Technical Reference (CSIRO Div. Wildlife \& Ecology, Canberra, 1992)

Box, E.O. Macroclimate and Plant Forms: An Introduction to Predictive Modelling (Junk, The Hague, 1981)

Woodward, F.I. Climate and Plant Distribution (Cambridge Studies in Ecology), (Cambridge University Press, Cambridge, 1987)

Du Rietz, G.E. Acta Phytogeogr. Suecica 3, 1-95 (1931).

Cain, S.A. Bot. Rev. 16, 1-32 (1950).

Fekete, G. \& Szujkó-Lacza, J. Ann. Hist.-Nat. Mus. Nation. Hungarici 64, 53-62 (1972).

Braun-Blanquet, J. Plant Sociology: The Study of Plant Communities (Engl. transl.) (McGrawHill, New York, 1932).

Ellenberg, H. \& Mueller-Dombois, D. Ber. geobot. Inst. ETH, Stiftg. Rube1 37, 21-35 (1966).

Mueller-Dombois, D. \& Ellenberg, H. Aims and Methods of Vegetation Ecology (Wiley, New York, 1974)

Orshan, G. Ecol. Stud. 43, 86-100 (1983). 
Grime, J.P. Plant Strategies and Vegetation Processes (Wiley, Chichester, 1979).

Noble, I.R. \& Slatyer, R.O. Vegetatio 43, 5-21 (1980).

Gillison, A.N. in Vegetation Classification in Australia (eds. Gillison, A.N. \& Anderson, D.J.) 30- 41 (CSIRO \& Australian National University Press, Canberra, 1981).

Johnson, R.A. J. Environ. Manage. 13, 205-222 (1981).

Bahr, L.M. Ecol. Model. 15, 2 1 1-233 (1982).

Vogel, K. in Constructional Morphology and Evolution (eds. Schmidt-Kittler, N. \& Vogel, K.) 54-68 (Springer Verlag, Berlin, 1991).

Nix, HA. \& Gillison, A.N. in Wildlife Management in the Forests and Forestry-Controlled Lands in the Tropics andthe Southern Hemisphere (ed. J. Kikkawa) 39-45 (I.U.F.R.O. S1.08 Wildlife and its Habitats, 1985).

Fox, B.J. \& Fox, M.D. in Vegetation Classification in Australia (eds. Gillison, A.N. \& Anderson, D.J.) 166-180 (CSIRO \& Australian National University Press,Canberra, 1981).

Gillison, A.N. A Plant Functional Proforma for Dynamic Vegetation Studies and Natural Resource Surveys (Tech. Mem. 8813, CSIRO Div. Water Resources,Canberra, 1988)

Wirth, N. Commun. Assoc. Comput. Mach. 20, 822-823 (1977).

Sankoff, D. \& Kruskal, J.B. (eds.). Time Warps, String Edits, and Macromolecules (The Theory And Practice of Sequence Comparison). (Addison-Wesley Publishing Co, Reading, Massachusetts, 1983).

Friedman, J.H. \& Rafsky, L.C. The Annals of Statistics, 7, 697-7 17 (1979).

Kirkpatrick, S, Gelatt, C.D. Jr. \& Vecchi, M.P. Science, 220, 671-680 (1983).

Prim, R.C. Bell Syst. Tech. J. 36, 1389-1401 (1957).

Box, E.O. Vegetatio 45, 127- 139 (1981)

Booth, T.H. Agroforestry Syst 10, 33-45 (1990)

Raup, D.M. J. Paleontol. 40, 1178-1190 (1966).

Kent, M. Vegetation Description and Analysis: a Practical Approach (CRC Press, Boca Raton, Fla, 1992).

Farris, J.S. Am. Nat. 106, 645-668 (1972).

Swofford, D.L. PAUP: Phylogenetic Analysis Using Parsimony (Natural History Survey, Champaign,IL, 1992)

Faith, D.P. Biol. Conserv. 61, 1-10 (1992). 


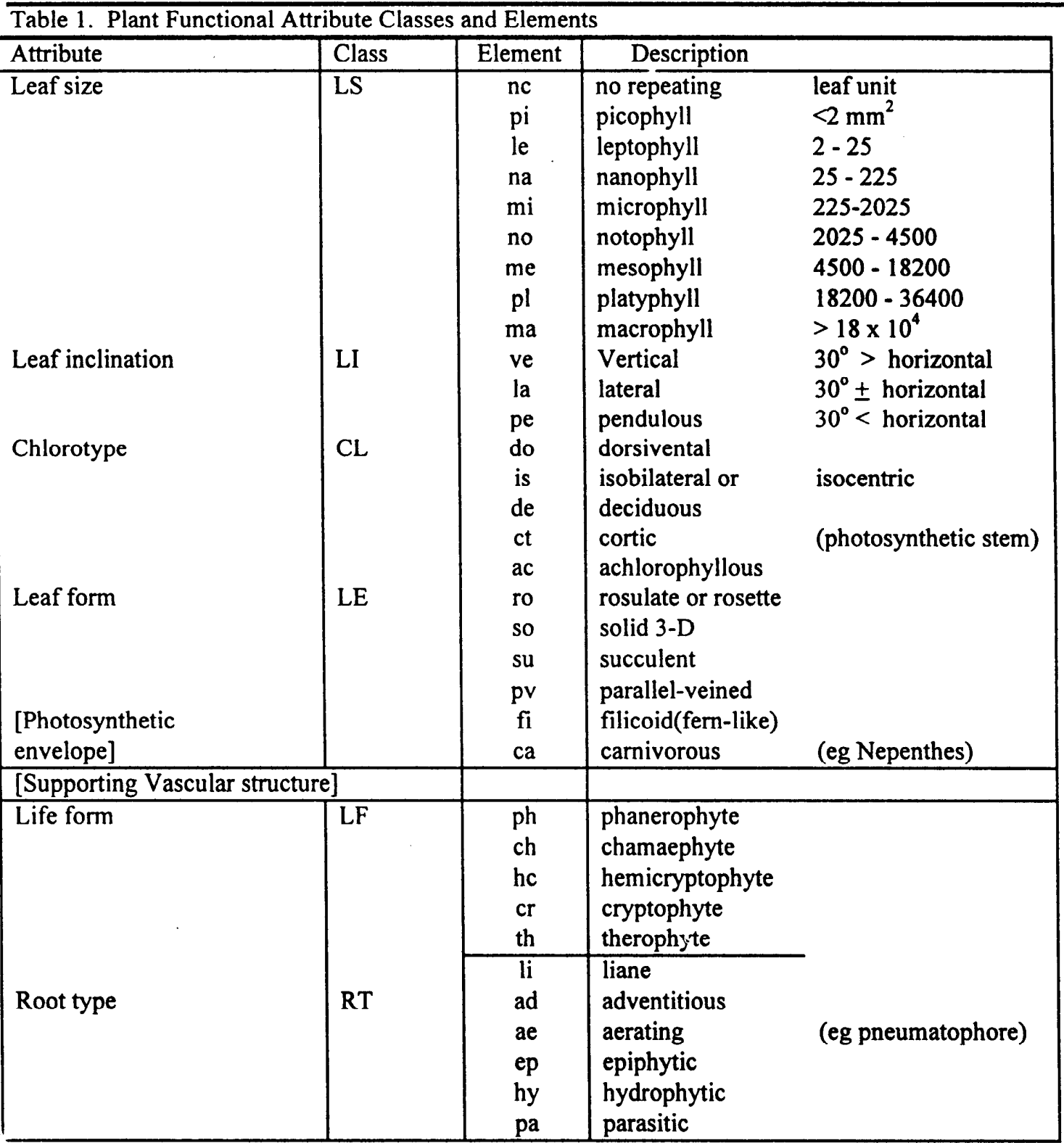

Table 2. Subjective transformation costs between modal elements listed in Table 1 .

\begin{tabular}{|c|c|c|c|c|c|c|}
\hline $\begin{array}{l}\text { Non- } \\
\text { repeating } \\
\text { leaf unit }\end{array}$ & $\begin{array}{l}\text { Leaf size } \\
\text { class }\end{array}$ & $\begin{array}{l}\text { Leaf incli- } \\
\text { nation }\end{array}$ & Chlorotype & Leaf form & $\begin{array}{l}\text { Raunkiaer } \\
\text { life form }\end{array}$ & Root type \\
\hline 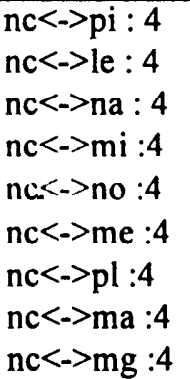 & $\begin{array}{l}\text { pi<->le }: 1 \\
\text { le<-> na }: 1 \\
\text { na<->mi }: 1 \\
\text { mi<->no }: 1 \\
\text { no<-> me }: 1 \\
\text { me<->pl }: 1 \\
\text { pl<->ma }: 1 \\
\text { ma<->mg: } 1\end{array}$ & $\begin{array}{l}\text { ve<->la }: 2 \\
\text { la<->pe }: 2 \\
\text { co<-> ve }: 2 \\
\text { co<->la }: 2 \\
\text { co<->pe }: 2\end{array}$ & $\begin{array}{l}\text { ac<->do :6 } \\
\text { ac<->is :6 } \\
\text { do<->is:3 } \\
\text { de<->* :3 } \\
\text { ct<->* :3 }\end{array}$ & $\begin{array}{l}\text { ro<->*:3 } \\
\text { so<->* :3 } \\
\text { su<->* :3 } \\
\text { pv<->*:3 } \\
\text { fi<-->* :3 } \\
\text { ca<->* :5 }\end{array}$ & $\begin{array}{l}\text { ph<->ch:3 } \\
\text { ch<->hc :3 } \\
\text { hc<->cr :3 } \\
\text { hy<->* :5 } \\
\text { th<->ph :5 } \\
\text { th<->ch :5 } \\
\text { th<->hc :5 } \\
\text { li <-> :3 }\end{array}$ & $\begin{array}{l}\text { ad<->* :3 } \\
\text { ae<->**:4 } \\
\text { ep<->* :3 } \\
\mathrm{pa}^{\circ}:>^{*}: 6\end{array}$ \\
\hline
\end{tabular}


Table 3. description of Global Sites for Modal Analyses

\begin{tabular}{|c|c|c|c|c|}
\hline $\begin{array}{l}\text { Site } \\
\text { code }\end{array}$ & Locality & Lat./Long. & $\begin{array}{l}\text { Elevn. } \\
\text { m.a.s.l. }\end{array}$ & Vegetation \\
\hline Cam & Campo, Cameroon & $02^{\circ} 25^{\prime} \mathrm{N}$ & 30 & $\begin{array}{l}\text { Megatherm maritime, } \\
\text { rain forest }\end{array}$ \\
\hline$\overline{I g z}$ & Iguazú, Argentina & $25^{\circ} 39^{\prime} \mathrm{S}$ & 300 & $\begin{array}{l}\text { Meso-megatherm, } \\
\text { rain forest }\end{array}$ \\
\hline FrG & $\begin{array}{l}\text { Petit Saut, } \\
\text { Fr.Guyana }\end{array}$ & $05^{\circ} 04^{\prime} \mathrm{N}$ & 100 & $\begin{array}{l}\text { Megatherm 'Terra firme' } \\
\text { rain forest }\end{array}$ \\
\hline FNQ & $\begin{array}{l}\text { Cairns, N. QId. } \\
\text { Australia } \\
\end{array}$ & $\begin{array}{l}17^{\circ} 00^{\prime} \mathrm{S} \\
145^{\circ} 44^{\prime} \mathrm{li}\end{array}$ & 50 & $\begin{array}{l}\text { Megatherm, maritime } \\
\text { lain forest }\end{array}$ \\
\hline$\overline{\text { PNG }}$ & $\begin{array}{l}\text { Lihir Isl. } \\
\text { Papua New Guinea }\end{array}$ & $\begin{array}{l}03^{\circ} 35^{\prime} \mathrm{S} \\
153^{\circ} 40^{\prime} \mathrm{E}\end{array}$ & 50 & $\begin{array}{l}\text { Megatherm, maritime } \\
\text { rain forest }\end{array}$ \\
\hline And & $\begin{array}{l}\text { Cordillera do } \\
\text { Merida, Venezuela }\end{array}$ & $\begin{array}{l}03^{\circ} 24^{\prime} \mathrm{N} \\
71^{\circ} 08^{\prime} \mathrm{W}\end{array}$ & 3500 & $\begin{array}{l}\text { Microtherm moist } \\
\text { Andean steppe }\end{array}$ \\
\hline Pat & $\begin{array}{l}\text { Pilcaniyeu, } \\
\text { Argentina }\end{array}$ & $\begin{array}{l}41^{\circ} 04^{\prime} \mathrm{S} \\
68^{\circ} 40^{\prime} \mathrm{W}\end{array}$ & 1200 & $\begin{array}{l}\text { Mesotherm dry } \\
\text { Patagonian steppe }\end{array}$ \\
\hline TdF & $\begin{array}{l}\text { Ushuaia NP, Tierra } \\
\text { del Fuego (Arg.) }\end{array}$ & $\begin{array}{l}54^{\circ} 48^{\prime} \mathrm{S} \\
68^{\circ} 20^{\prime} \mathrm{W}\end{array}$ & 40 & Microtherm moist beech forest \\
\hline Mac & $\begin{array}{l}\text { Macquarie Isl. } \\
\text { Sub-Antarctic }\end{array}$ & $\begin{array}{l}54^{\circ} 30^{\prime} \mathrm{S} \\
158^{\circ} 56^{\prime} \mathrm{E}\end{array}$ & 20 & Mcrotherm maritime tundra \\
\hline Ice & $\begin{array}{l}\text { Reykjanes } \\
\text { Peninsula, Iceland }\end{array}$ & $\begin{array}{l}63^{\circ} 50^{\prime} \mathrm{N} \\
22^{\circ} 42^{\prime} \mathrm{W}\end{array}$ & 10 & Microtherm maritime tundra \\
\hline
\end{tabular}

All vegetation variously disturbed by logging or grazing or fire. Thermal zones after Schimper.

Table 4. Description of Sites Along a Regional Climate Gradient in Far North Queensland

\begin{tabular}{|c|c|c|c|}
\hline $\begin{array}{l}\text { Site } \\
\text { no }\end{array}$ & $\begin{array}{l}\text { Rainfall \# } \\
\text { seasonality }\end{array}$ & $\begin{array}{l}\text { Minimum air } \\
\text { temp }{ }^{\circ} \mathrm{C}\end{array}$ & Vegetation description \\
\hline a) & 69 & 8.1 & $\begin{array}{l}\text { Rain forest dominated by Kauri pine (Agathis } \\
\text { atropurpureum) }\end{array}$ \\
\hline b) & 71 & 8.4 & $\begin{array}{l}\text { Rain forest without Kauri pine, numerous lianes, } \\
\text { epiphytes }\end{array}$ \\
\hline c) & 68 & 7.8 & Rcently-regenerating rain forest on disturbed site \\
\hline d) & 77 & 8.9 & $\begin{array}{l}\text { Mixed rain forest and wet sclerophyll (Eucalyptus } \\
\text { grandis, E. resinifera) emergents on disturbed site }\end{array}$ \\
\hline e) & 77 & 8.9 & $\begin{array}{l}\text { Drier aspect of wet sclerophyll forest with } \\
\text { graminoid understorey and } E \text {. grandis, } E \text {. } \\
\text { resinifera dominants; infrequent wildfire. }\end{array}$ \\
\hline f) & 99 & 10.3 & $\begin{array}{l}\text { Tall, open forest with graminoid understorey, } \\
\text { dominated by Euc. citriodora, E. crebra; fired } \\
\text { semi-annually. }\end{array}$ \\
\hline
\end{tabular}

\# Coefficient of Variation percent of monthly rainfall. 


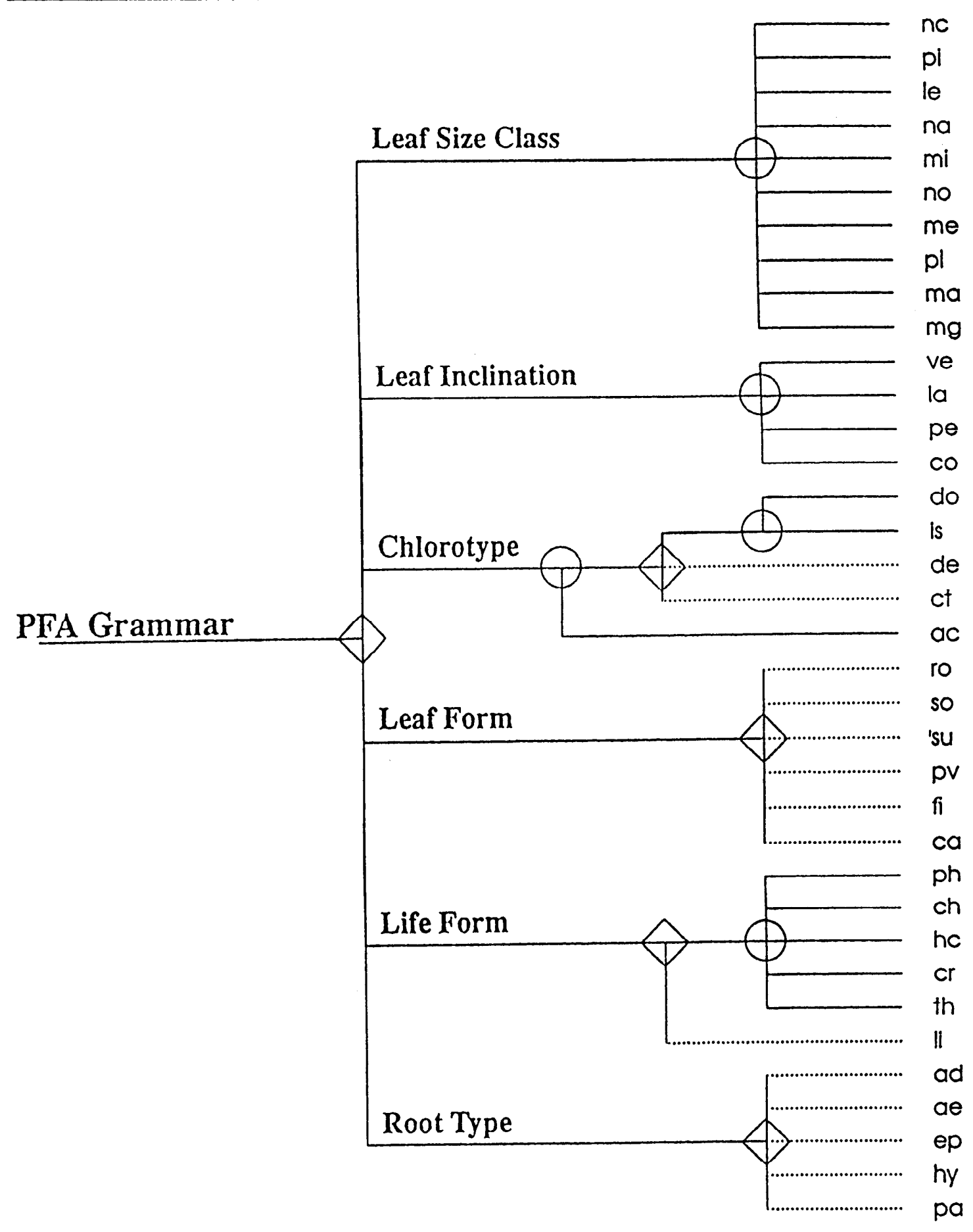

$X=$ LS LI CL LE LF RT

$\mathrm{LS}=\mathrm{nc}|\mathrm{pi}| \mathrm{le}|\mathrm{na}| \mathrm{mi}|\mathrm{no}| \mathrm{me}|\mathrm{pl} / \mathrm{ma}| \mathrm{mg}$

$\mathrm{LI}=\mathrm{ve}|\mathrm{la}| \mathrm{pc} \mid \mathrm{co}$

$\mathrm{CL} \equiv((\mathrm{do} \mid \mathrm{is})[\mathrm{de}][\mathrm{ct}]) \mid \mathrm{ac}$

$\mathrm{LE}=[\mathrm{ro}][\mathrm{so}][\mathrm{su}][\mathrm{pv}][\mathrm{fi}][\mathrm{ca}]$

$\mathrm{LF}=(\mathrm{ph}|\mathrm{ch}| \mathrm{hc}|\mathrm{cr}| \mathrm{th})[\mathrm{li}]$

$\mathrm{RT}=[\mathrm{ad}][\mathrm{ac}][\mathrm{ep}][\mathrm{hy}][\mathrm{pa}]$

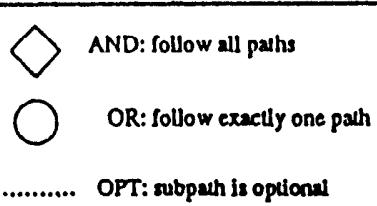

Figure 1. Grammar structure for 36 plant functional elements contained within 6 attribute classes (Table 1). The Backus-Naur notation is displayed at lower left. 


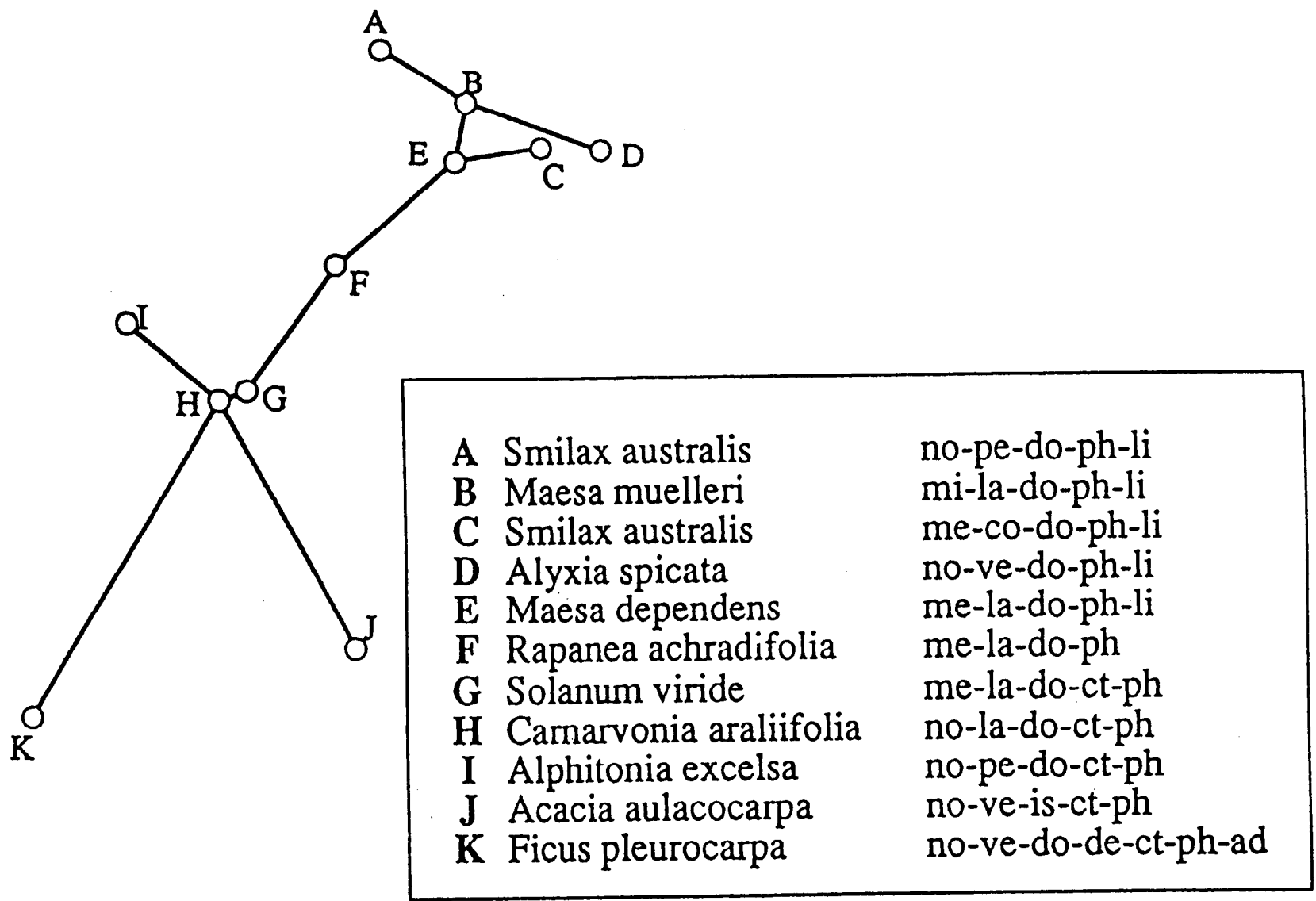

Figure 2. Minimum Spanning Tree generated from the distance matrix for all plant functional modi within one rain-forested locality in the Lamb Range, far north Queensland, Australia. The figure shows infra-specific variability in functional elements within Smilax australis and indicates how a liane cluster (li) is distinguished from non-lianoid woody plants with and without photosynthetic stem tissue (t) and adventitious rooting (ad). Inter-medal distances are computed from the cumulative cost of transformations required to translate between modi using a table of transformation costs (Table 2). MST node positions were determined using a simulated annealing optimization method which attempts to minimise stress between the distance matrix and the $2-d$ node distances. The Minimum Spanning Tree links shown were given twice the priority of the other links for optimization. 


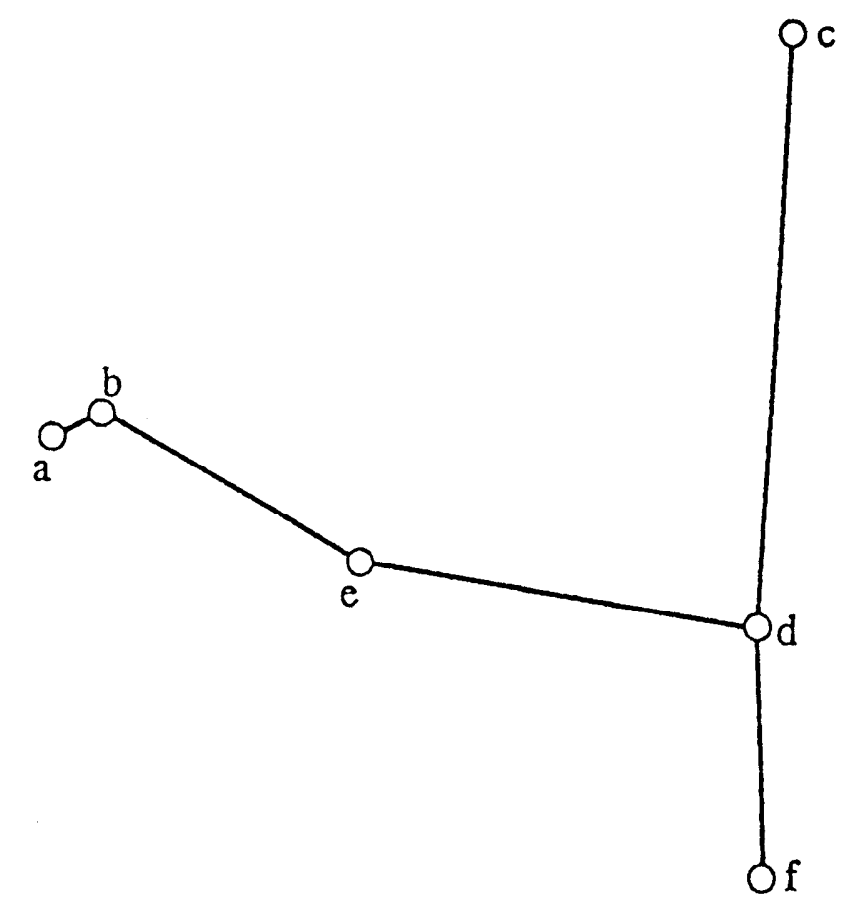

\begin{tabular}{|c|c|c|c|c|c|}
\hline $\begin{array}{l}0.00 \\
0.03 \\
4.37 \\
3.66 \\
0.88 \\
4.14\end{array}$ & $\begin{array}{l}0.00 \\
2.70 \\
5.38 \\
0.37 \\
3.77\end{array}$ & $\begin{array}{l}0.00 \\
1.65 \\
3.91 \\
5.61\end{array}$ & $\begin{array}{l}0.00 \\
0.55 \\
0.20\end{array}$ & $\begin{array}{l}0.00 \\
2.04\end{array}$ & 0.00 \\
\hline a & b & c & $d$ & $\mathrm{e}$ & $f$ \\
\hline
\end{tabular}

Figure 3. Minimum Spanning Tree of vegetated sitcs along rainfall seasonality and disturbance g,radients in the Lamb Range (North Qld Australia). a). $\Lambda$ Kauri pine (Agathis atropurpurea)

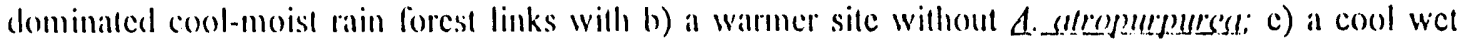
sclerophy'll, eucalypt-dominated forest (l) a disturbed wet sclerophyll forest with cucalypts and successional rain forest elements, c) a highly-disturbed, early successional rain forest, I) a tall open forest dominated by cucalypts, subject to frequent wildfire. The overlap of plant functional modi along the tree indicates a graded response to both seasonality and fire history. Distances are computed using a multidimensional generalisation of the Wald-Wolfowitz two sample test. Node positions are determined as for Figure 2. 


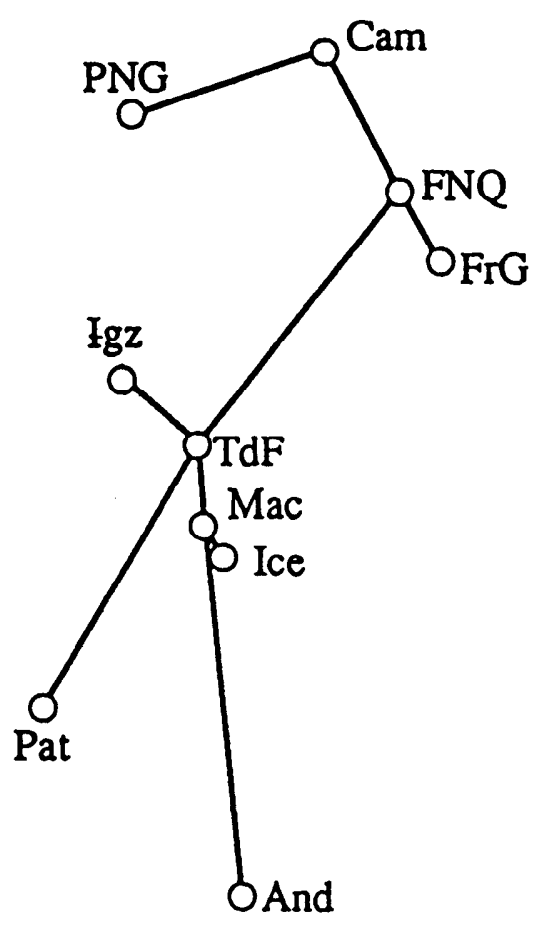

\begin{tabular}{|c|c|c|c|c|c|c|c|c|c|c|}
\hline $\begin{array}{l}\text { Cam } \\
\text { Igz } \\
\text { FrG } \\
\text { FNQ } \\
\text { PNG } \\
\text { And } \\
\text { Pat } \\
\text { TdF } \\
\text { Mac } \\
\text { Ice }\end{array}$ & $\begin{array}{l}0.00 \\
3.67 \\
2.49 \\
1.74 \\
2.14 \\
8.43 \\
7.04 \\
3.48 \\
3.23 \\
4.57\end{array}$ & $\begin{array}{l}0.00 \\
4.96 \\
3.47 \\
2.88 \\
4.79 \\
4.65 \\
0.12 \\
0.78 \\
2.61\end{array}$ & $\begin{array}{l}0.00 \\
0.54 \\
2.73 \\
6.63 \\
6.52 \\
2.44 \\
1.52 \\
3.46\end{array}$ & $\begin{array}{l}0.00 \\
2.73 \\
8.97 \\
8.39 \\
0.87 \\
2.52 \\
4.01\end{array}$ & $\begin{array}{l}0.00 \\
7.22 \\
5.91 \\
3.49 \\
3.18 \\
4.48\end{array}$ & $\begin{array}{l}0.00 \\
2.94 \\
3.15 \\
1.59 \\
3.76\end{array}$ & $\begin{array}{l}0.00 \\
1.10 \\
1.37 \\
2.05\end{array}$ & $\begin{array}{l}0.00 \\
0.70 \\
1.25\end{array}$ & $\begin{array}{l}0.00 \\
0.15\end{array}$ & 0.00 \\
\hline & Cam & $\operatorname{Ig} z$ & FrG & FNQ & PNG & And & Pat & $\mathrm{TdF}$ & Mac & Ice \\
\hline
\end{tabular}

Figure 4. Minimum Spanning Tree of widely differing sites at global scale (Table 3). Linkage cluster PNG-Cam-FNQ-FrG groups similar plant functional modi in tropical, maritime, megatherm, lowland sites; linkage FNQ-TdF-Igz shows a gradation of modi from moist-megatherm FNQ (far N. Qld) to moist-microtherm TdF (Tierra del Fuego) to disturbed inland continental, moist mesotherm rain forest Igz (Iguazú); TdF-Pat grades to dry-mesotherm, Patagonian steppe; TdF-Mac-Ice illustrates a gradation from microtherm Fuegian beech forest to more extreme microtherm maritime steppe in closely related environments at sub-polar extremes (Macquarie Island, Sub-Antarctic and Iceland); the last being connected to tropic-alpine Andean steppe in Venezuela. Distances are computed as for Fig.3. The pattern illustrates functional congruence at global environmental extremes. 